\title{
PENGARUH FAKTOR EKSTERNAL TERHADAP PIUTANG TAK TERTAGIH PADA KOPERASI GURU RAMBATE RATA (KGRR) TINAMBUNG KABUPATEN POLEWALI MANDAR
}

\section{The Effects of the External Factors toward Bad Debts in Koperasi Guru Rambate Rata (KGRR) Tinambung, Polewali Mandar Regency}

\author{
Dahlia \\ Email: dahlia@unsulbar.ac.id \\ Prodi Akuntansi Fakultas Ekonomi Unsulbar \\ J1.Prof. Baharuddin Lopa, S Talumung Majene Sulawesi Barat \\ Wiwi Purwati \\ Email: wiwipurwati75@gmail.com
}

\begin{abstract}
ABSTRAK
Penelitian ini bertujuan untuk mengetahui: pengaruh Faktor Eksternal terhadap Piutang Tak Tertagih pada Koperasi Guru Rambate Rata (KGRR) Tinambung Kabupaten Polewali Mandar. Populasi penelitian ini adalah 33 orang anggota koperasi yang terindikasi atau yang termasuk mempunyai piutang tak tertagih pada Koperasi Guru Rambate Rata (KGRR) Tinambung Kabupaten Polewali Mandar. Data penelitian di perolah dengan menggunakan instrument kuesioner dan wawancara. Uji hipotesis yang digunakan adalah regresi linier sederhana dan uji t. Hasil penelitian ini menunjukkan bahwa: Faktor Eksternal berpengaruh positif terhadap Piutang Tak Tertagih pada Koperasi Guru Rambate Rata (KGRR) Tinambung Kabupaten Polewali Mandar yang ditunjukkan dengan nilai koefisien determinasi sebesar 0,456 , nilai signifikansi lebih kecil dari level of significant $(0,000<0,050)$ dan persamaan garis regresinya.
\end{abstract}

Kata Kunci: faktor eksternal; piutang tak tertagih.

\section{ABSTRACT}

This research is aimed to know: the effects of the External Factors toward Bad Debts in Koperasi Guru Rambate Rata (KGRR) Tinambung, Polewali Mandar Regency. The population of this 33 members of the Koperasi Guru Rambate Rata (KGRR) who are indicated to or currently have bad debts to Koperasi Guru Rambate Rata (KGRR) Tinambung, Polewali Mandar Regency. The data of this research are acequired tharough questionaries and interviews.. Hypothesis tests that will be used are simple linier regression and t test. The research shows that: The External Factors have positive effect toward Bad Debts in Koperasi Guru Rambate Rata (KGRR) Tinambung, Polewali Mandar Regency, shown by the coefficient of determination of 0,456, with smaller significanse value of the level of significant $(0,000<0,050)$ and equal regression line.

Keywords: external factors; bad debts. 


\section{PENDAHULUAN}

Salah satu pelayanan jasa dalam koperasi adalah pemberian pinjaman baik berupa uang maupun berupa barang. Dalam pemberian pinjaman ini akan menimbulkan munculnya piutang bagi pihak memberikan pinjaman (kreditur) dan utang bagi pihak yang menerima pinjaman (debitur). Piutang merupakan salah satu unsur dari aktiva lancar yang ada dalam neraca perusahaan. Menurut Sugiri (2009:43) Piutang adalah tagihan baik kepada individu - individu maupun kepada perusahaan lain yang akan diterima dalam bentuk kas.

Piutang timbul karena adanya penjualan barang dan jasa atau karena adanya pemberian kredit kepada debitur yang pembayarannya dilakukan dalam bentuk angsuran atau tidak secara tunai (Kredit) yang diberikan oleh perusahaan dapat menyebabkan piutang tak tertagih dan perusahaan pasti memiliki beberapa pelanggan yang tidak sanggup membayar atau akan melunasi hutang mereka. Rekening pelanggan seperti itu umumnya disebut sebagai piutang tak tertagih. Menurut Hery (2014:186) Piutang tak tertagih adalah timbul adanya pelanggan yang tidak bisa membayar karena menurunnya omzet penjualan sebagai akibat dari lesunya perekonomian dan kebangkitan dialami oleh debitur.

Oleh karena itu tidak dapat dipungkiri bahwa pengendalian piutang merupakan suatu perangkat alat yang perlu dilaksanakan dengan sebaik - baiknya, karena piutang yang tidak dapat ditagih merupakan salah satu faktor yang akan merugikan perusahaan. Dengan kata lain resiko tidak tertagihnya piutang dari para nasabah merupakan tanggung jawab bersama diantara fungsionaris perusahaan. Untuk mengantisipasi timbulnya piutang akibat tidak tertagihnya piutang, maka sebelum perusahaan memberikan pinjaman atau menambah pinjaman sebelumnya, pihak perusahaan terlebih dahulu mengadakan evaluasi tentang keadaan atau kemampuan ekonomis calon nasabah.

Adapun pengertian piutang Menurut Martini (2012:193) Piutang adalah klaim suatu perusahaan pada pihak lain. Sedangkan Menurut Mulya (2010:198) Piutang adalah berupa hak klaim atau tagihan berupa uang atau bentuk lainnya kepada seseorang atau suatu perusahaan. Sedangkan Menurut Kieso, dkk (2013:512) Istilah Piutang didefinisikan sebagai jumlah yang dapat ditagih dalam bentuk tunai dari seseorang atau perusahaan lain. Sedangkan Menurut Hery (2014:29) Istilah Piutang mengacu pada sejumlah tagihan yang akan diterima oleh perusahaan (umumnya dalam bentuk kas) dari pihak lain, baik sebagai akibat penyerahan barang dan jasa secara kredit (untuk piutang pelanggan yang terdiri atas piutang usaha dan memungkinkan piutang wesel), memberikan pinjaman (untuk piutang karyawan, piutang debitur yang biasanya langsung dalam bentuk piutang wesel, piutang bunga), maupun sebagai 
akibat kelebihan pembayaran kas kepada pihak lain (untuk piutang pajak), Dan Menurut Harti (2011:98) Piutang merupakan klaim / tagihan perusahaan terhadap pihak ketiga yang timbul karena adanya suatu transaksi.

Menurut Rivai, dkk (2013:239) Faktor Eksternal yang mempengaruhi piutang tak tertagih diantaranya yaitu : menurunnya kondisi ekonomi, adanya salah urus dalam pengelolaan usaha, problem keluarga, kegagalan debitur pada bidang usaha atau perusahaan mereka yang lain, munculnya kejadian di luar kekuasaan debitur, misalnya perang dan bencana alam dan watak buruk debitur (yang semula memang merencanakan tidak akan melunasi piutangnya). Adapun pengertian piutang tak tertagih Menurut Feryanto (2010:56) Piutang tak tertagih adalah risiko yang diterima akibat tidak tertagihnya piutang dagang karena pelanggan tidak membayar. Sedangkan Menurut Kieso, dkk (2009:350) Piutang tak tertagih adalah kerugian pendapatan yang memerlukan ayat jurnal pencatatan yang tepat dalam akun, penurunan aktiva piutang serta penurunan yang berkaitan dengan laba dan ekuitas pemegang saham. Dari pengertian diatas dapat disimpulkan bahwa piutang tak tertagih adalah risiko yang diterima akibat tidak tertagihnya piutang dagang maupun jasa karena nasabah tidak membayar dan mengakibatkan penurunan aktiva piutang serta penurunan yang berkaitan dengan laba dan ekuitas pemegang saham.

Menurut Suyatno (2007:118) Kasus kredit macet hampir tidak dapat dipisahkan dari aktivitas perusahaan. Pada sejumlah kredit, indikasi utama ke arah terjadinya kredit macet adalah gagalnya nasabah memenuhi kewajibannya untuk membayar kredit sesuai dengan jadwal yang disepakati. Terjadinya kredit macet dikarenakan adanya kelemahan dari dalam diri nasabah seperti adanya kelemahan dalam memasarkan produk yang dihasilkan selain itu, kebijakan pengaturan keuangan / permodalan yang diterima dari pihak ketiga juga akan mempengaruhi kemampuan nasabah didalam melunasi kewajiban. Nasabah yang memiliki permodalan yang tidak cukup untuk menjalankan usaha sehingga harus meminjam dari pihak ketiga dan tanpa ada pengelolaan yang baik maka modal dari pihak ketiga justru akan menjadi masalah dikemudian hari.

Koperasi Guru Rambate Rata (KGRR) merupakan salah satu koperasi yang ada di Kecamatan Tinambung Kabupaten Polewali Mandar yang lokasinya \pm 100 meter dari jalan poros Majene yang berdiri sejak tahun 1952 yang dipelopori oleh Bapak Atjo Daeng Tjora dan Ibrahim. Pada awalnya Koperasi Guru Rambate Rata dinamakan dengan Koperasi Guru Balanipa (KOGUBA) dan seiring berkembangnya koperasi tersebut maka pada tahun 1960 mengadakan rapat tentang pemberian nama yang tepat untuk koperasi tersebut dan pada akhirnya koperasi tersebut diberi nama Koperasi Guru Rambate Rata (KGRR) dan nama 
tersebut digunakan sampai saat ini tahun 2017. Koperasi Guru Rambate Rata merupakan salah satu koperasi simpan pinjam yang dimana kegiatan operasi utamanya yaitu menerima simpanan anggota dan menyalurkan kembali kepada anggota yang membutuhkan pinjaman modal untuk membuka dan meningkatkan usahanya dalam bentuk kredit jangka pendek terkhusus kepada yang berprofesi sebagai guru.

Berdasarkan wawancara awal dengan Najamuddin S.Pd.,M.pd selaku ketua Koperasi Guru Rambate Rata (KGRR) Tinambung, Kabupaten Polewali Mandar mengatakan bahwa:

"Dalam kegiatan operasi simpan pinjam Koperasi Guru Rambate Rata (KGRR) pada bulan Januari 2017 memiliki sebesar Rp.50.000.000; piutang yang tidak dapat ditagih atau biasa disebut dengan piutang tak tertagih, belum lagi piutang tak tertagih pada bulan dan tahun sebelumnya yang masih ada sebagian piutang yang belum diterima oleh Koperasi Guru Rambate Rata (KGRR)".

Kerugian yang timbul dari piutang yang tidak tertagih tersebut oleh bagian akuntansi diakui sebagai kerugian piutang. Penyebab piutang tak tertagih dari segi pemilik piutang karena kurangnya usaha penagihan, kurangnya kontrol atau kurangnya analisis seleksi dalam pemberian kredit dalam hal ini jika nasabah telat membayar piutang mereka pihak koperasi hanya melakukan penyelesaian yang bersifat kekeluargaan atau secara sosial bukan secara yuridis atau hukum jadi nasabah tidak merasakan keterpaksaan dalam melunasi kewajibannya sedangkan dari segi pihak yang berutang atau nasabah yang disebut sebagai faktor eksternal telat atau tidak mampu membayar pinjaman atau angsuran pinjaman mereka di Koperasi Guru Rambate Rata (KGRR) Tinambung, karena masih kurangnya kesadaran mereka dalam melunasi utangnya dan penyebab nasabah biasanya tidak tepat waktu atau pembayaran mereka macet dalam melunasi kewajibannya bisa bermacam - macam misalnya faktor nasabah tiba tiba mengalami kesulitan keuangan, bangkrutnya usaha yang dijalankan atau pihak yang berutang memang mempunyai motif secara sengaja tidak ingin membayar hutannya.

Berdasarkan latar belakang masalah yang telah diuraikan sebelumnya, maka perumusan masalah dalam penelitian ini adalah Bagaimana pengaruh Faktor Eksternal terhadap Piutang Tak Tertagih pada Koperasi Guru Rambate Rata (KGRR) Tinambung, Kab. Polewali Mandar. Tujuan penelitian dalam penelitian ini adalah Untuk mengetahui pengaruh Faktor Eksternal terhadap Piutang Tak Tertagih pada Koperasi Guru Rambate Rata (KGRR) Tinambung, Kab. Polewali Mandar. 


\section{METODE PENELITIAN}

Rancangan penelitian yang digunakan dalam penelitian ini adalah deskriptif kuantitatif yang merupakan penelitian yang digunakan bertujuan menjelaskan, meringkaskan, berbagai kondisi dan berbagai situasi yang timbul dimasyarakat yang menjadi objek penelitian tersebut berdasarkan apa yang terjadi. Penelitian ini dilakukan dengan metode survey dan informasi dikumpulkan menggunakan kuesioner. Menurut Sugiyono (2016:7) disebut metode kuantitatif karena data penelitian berupa angka - angka dan analisis menggunakan statik. Penelitian ini mengadakan akumulasi data secara kuesioner untuk memberikan gambaran - gambaran fenomena apakah yang menjadi faktor ekternal yang mempengaruhi piutang tak tertagih pada Koperasi Guru Rambate Rata (KGRR) Tinambung, Kabupaten Polewali Mandar.

Lokasi pada penelitian ini yang dilakukan oleh penulis yaitu Pada Koperasi Guru Rambate Rata (KGRR) Tinambung, Kab. Polewali Mandar. Waktu dalam penelitian ini yang akan dilakukan oleh penulis yaitu dilaksanakan pada bulan April sampai dengan bulan Mei 2017. Populasi dalam penelitian ini adalah 33 orang anggota koperasi yang terindikasi atau yang termasuk mempunyai piutang tak tertagih pada Koperasi Guru Rambate Rata (KGRR) Tinambung Kabupaten Polewali Mandar. Sampel dalam penelitian ini yaitu berjumlah 33 orang anggota koperasi yang terindikasi atau termasuk mempunyai piutang tak tertagih pada Koperasi Guru Rambate Rata (KGRR) Tinambung Kabupaten Polewali Mandar. Adapun teknik pengambilan sampel dalam penelitian ini adalah menggunakan Teknik Sampling Purposive. Menurut Sugiyono (2016:85) Sampling Purposive adalah teknik penentuan sampel dengan pertimbangan tertentu. Pertimbangan tertentu dalam teknik pengambilan sampel ini yaitu nasabah koperasi yang terindikasi atau termasuk dalam kategori yang mempunyai piutang tak tertagih (kredit macet) pada Koperasi Guru Rambate Rata (KGRR) Tinambung, Kabupaten Polewali Mandar.

Teknik Analisis Data dalam penelitian ini dilakukan melalui :

\section{a. Uji Validitas}

Kuesioner merupakan salah satu alat yang digunakan dalam pengumpulan data sebagai instrumen yang paling penting yang harus dilakukan pengujian terlebih dahulu. Uji validitas dilakukan dengan cara menguji kolerasi antara skor item dengan skor total masing-masing variabel. Secara statistik, angka kolerasi bagian total yang diperoleh harus dibandingkan dengan angka dalam tabel r produk moment. Apabila nilai uji validitas lebih dari (>) nilai standar maka kuesioner tersebut dapat dikatakan valid dan sebaliknya. 
b. Uji Reliabilitas

Uji reliabilitas menggunakan metode Croncbach's Alpha Menurut Jogiyanto (2008:141) bahwa di tahapan - tahapan awal dari riset nilai reliabilitas 0,6 dianggap cukup dan untuk riset dasar diargumentasikan bahwa meningkatkan reliabilitas melebihi nilai 0,8 sering dianggap terlalu tinggi.

c. Analisis Regresi Linier Sederhana

Teknik Analisis data pada penelitian ini menggunakan analisis regresi linier sederhana yaitu hubungan secara linier antara satu variabel independen $(\mathrm{X})$ dengan variabel dependen (Y). Menurut Sugiyono (2016:188) Analisis ini untuk melakukan prediksi seberapa tinggi nilai variabel dependen bila nilai variabel independen dimanipulasi (dirubah - rubah).

Rumus regresi linier sederhana adalah sebagai berikut:

$$
Y^{\prime}=a+\beta X
$$

Keterangan:

$Y^{\prime}=$ Piutang Tak Tertagih

$X=$ Faktor Ekternal

$a=$ Konstanta (nilai $\mathrm{Y}^{\prime}$ apabila $\mathrm{X}=0$ )

$\beta=$ Koefisien regresi (nilai peningkatan ataupun penurunan)

Untuk menghitung nilai a dan $\beta$ ini menggunakan program komputer statistik yaitu SPSS.

d. Uji Hipotesis ( Uji t )

Menurut Sugiyono (2016:195) Yaitu uji yang digunakan untuk mengetahui secara partial pengaruh variabel independen dengan dependen.

c. Kriteria pengujian :

1. Jika t hitung $>$ t table, Ho ditolak dan Ha diterima hal ini berarti bahwa ada hubungan variabel independen dengan variabel dependen.

2. Jika nilai $\mathrm{t}$ hitung $<\mathrm{t}$ table, Ho diterima dan Ha ditolak hal ini berarti bahwa tidak ada hubungan variabel independen dengan variabel dependen.

e. Koefisien Determinasi

Menurut Ghozali (2012:97) Koefisien determinasi $\left(r^{2}\right)$ merupakan alat untuk mengukur seberapa jauh kemampuan model dalam menerangkan variasi variabel dependen. Koefisien determinasi dan regresi sederhana menunjukkan tingkat kejelasan yang dapat diberikan oleh model tersebut terhadap perubahan variabel dependen. Nilai koefisien determinasi menunjukkan persentase variasi nilai variabel devenden yang dapat dijelaskan oleh persamaan regresi yang dihasilkan. 


\section{HASIL DAN PEMBAHASAN}

\section{Analisis Deskriptif Variabel Penelitian}

\section{a. Analisis Deskriptif Faktor Eksternal (X)}

Penelitian ini dilakukan di Koperasi Guru Rambate Rata (KGRR) Tinambung, Kabupaten Polewali Mandar, dengan responden sebanyak 33 anggota koperasi. Pengumpulan data dilakukan pada tanggal 20 April 2017 sampai dengan 9 Mei 2017 dengan cara membagikan kuesioner secara langsung kepada anggota koperasi. Jumlah kuesioner yang terbagikan sebanyak 33 buah dan semuanya terkumpul kembali.

\section{b. Analisis Deskriptif Piutang Tak Tertagih (Y)}

Selain hal - hal yang mendorong para guru untuk memutuskan mengambil pinjaman di Koperasi Guru Rambate Rata (KGRR) Tinambung yang peneliti amati selama melakukan penelitian di koperasi tersebut, adapun hal - hal yang menyebabkan terjadinya atau timbulnya piutang tak tertagih dikoperasi tersebut. Dari segi pihak berutang atau anggota koperasi yang menyebabkan telat atau tidak mampu membayar angsuran pinjaman mereka di Koperasi Guru Rambate Rata (KGRR) Tinambung adalah:

a. Kurangnya kesadaran sebagian kecil anggota koperasi untuk melunasi pinjaman mereka.

b. Anggota koperasi mengalami kesulitan kondisi keuangan.

c. Adanya kebutuhan yang tiba - tiba mendesak yang harus diselesaikan seperti pembayaran kuliah anak, salah satu keluarga mendapatkan musibah (sakit atau kecelakaan) dan lain sebagainya.

d. Sebagian kecil anggota koperasi mempunyai motif atau niat secara sengaja tidak ingin melunasi pinjaman mereka.

Berikut dapat dilihat tabel data piutang tak tertagih pada Koperasi Guru Rambate Rata (KGRR) Tinambung, Kabupaten Polewali Mandar yaitu:

Tabel 1. Data Piutang Tak Tertagih Koperasi Guru Rambate Rata (KGRR) Tinambung, Kabupaten Polewali Mandar

\begin{tabular}{|c|c|}
\hline Tahun & Jumlah \\
\hline 2013 & Rp. 26.055 .388 \\
\hline 2014 & Rp. 25.626 .076 \\
\hline 2015 & Rp. 25.626 .076 \\
\hline 2016 & Rp. 54.767.487 \\
\hline
\end{tabular}

Sumber: Laporan Keuangan KGRR 2013 - 2016 
Dari tabel diatas dapat dijelaskan bahwa piutang tak tertagih pada tahun 2013 sebesar Rp.26.055.388 dan dari tahun 2013 ke tahun 2014 piutang tak tertagih mengalami penurunan sebesar Rp.429.312 sedangkan pada tahun 2014 ke tahun 2015 tidak mengalami perubahan yang disebabkan karena sebagian anggota dimutasi jauh dari tempat kerja sebelumnya dan sebagian anggota meninggal dunia serta ahli waris belum siap atau belum sanggup untuk membayar sedangkan usaha penagihan yang dilakukan oleh pihak koperasi yaitu hanya menyurat. Piutang tak tertagih pada tahun 2015 ke tahun 2016 mengalami peningkatan sebesar Rp.29.141.410 yang disebabkan karena adanya tambahan satu orang anggota koperasi yang mempunyai piutang tak tertagih berupa pinjaman barang atau uang yang melebihi dari satu kali dan tiba - tiba macet karena mengalami kesulitan kondisi keuangan dan mendapatkan mutasi kerja jauh dari daerah sebelumnya.

\section{c. Hasil Kuisioner}

Berdasarkan hasil survei dengan menggunakan kuesioner maka didapat jawaban untuk setiap pernyataan variabel faktor eksternal yaitu:

Tabel 2. Distribusi Frekuensi Faktor Eksternal

\begin{tabular}{|c|c|c|c|c|c|c|c|c|c|c|}
\hline \multirow[t]{2}{*}{ Pernyataan } & \multicolumn{2}{|c|}{$\begin{array}{l}\text { (1) Tidak } \\
\text { Pernah }\end{array}$} & \multicolumn{2}{|c|}{ (2) Jarang } & \multicolumn{2}{|c|}{$\begin{array}{l}\text { (3) Kadang - } \\
\text { kadang }\end{array}$} & \multicolumn{2}{|c|}{ (4) Sering } & \multicolumn{2}{|c|}{ (5) Selalu } \\
\hline & $\sum$ & $(\%)$ & $\sum$ & $(\%)$ & $\sum$ & $(\%)$ & $\sum$ & $(\%)$ & $\sum$ & $(\%)$ \\
\hline 1 & 0 & $0 \%$ & 0 & $0 \%$ & 10 & $30,3 \%$ & 4 & $12,1 \%$ & 19 & $57,6 \%$ \\
\hline 2 & 0 & $0 \%$ & 0 & $0 \%$ & 13 & $39,4 \%$ & 7 & $21,2 \%$ & 13 & $39,4 \%$ \\
\hline 3 & 0 & $0 \%$ & 1 & $3 \%$ & 1 & $3 \%$ & 3 & $9,1 \%$ & 28 & $84,9 \%$ \\
\hline 4 & 0 & $0 \%$ & 1 & $3 \%$ & 17 & $51,5 \%$ & 5 & $15,2 \%$ & 10 & $30,3 \%$ \\
\hline 5 & 0 & $0 \%$ & 8 & 24,2 & 24 & $72,8 \%$ & 1 & $3 \%$ & 0 & $0 \%$ \\
\hline 6 & 0 & $0 \%$ & 0 & $0 \%$ & 17 & $52,5 \%$ & 9 & $27,3 \%$ & 7 & $21,2 \%$ \\
\hline 7 & 0 & $0 \%$ & 0 & $0 \%$ & 3 & $9,1 \%$ & 8 & $24,2 \%$ & 22 & $66,7 \%$ \\
\hline 8 & 0 & $0 \%$ & 1 & $3 \%$ & 17 & $52,5 \%$ & 6 & $18,2 \%$ & 9 & $27,3 \%$ \\
\hline 9 & 0 & $0 \%$ & $\begin{array}{l}1 \\
4\end{array}$ & 42,4 & 15 & $45,4 \%$ & 2 & $6,1 \%$ & 2 & $6,1 \%$ \\
\hline 10 & 0 & $0 \%$ & 1 & $3 \%$ & 22 & $66,7 \%$ & 7 & $21,2 \%$ & 3 & $9,1 \%$ \\
\hline 11 & 0 & $0 \%$ & 1 & $3 \%$ & 12 & $36,4 \%$ & 10 & $30,3 \%$ & 10 & $30,3 \%$ \\
\hline 12 & 0 & $0 \%$ & 0 & $0 \%$ & 4 & $12,1 \%$ & 7 & $21,2 \%$ & 22 & $66,7 \%$ \\
\hline Total & 0 & & 2 & & 155 & & 69 & & 145 & \\
\hline
\end{tabular}


Dari pembahasan diatas dapat disimpulkan bahwa semua responden tidak ada yang memilih kategori pernyataan tidak pernah dalam menjawab pernyataan - pernyataan tentang faktor eksternal sehingga dapat dikatakan bahwa jawaban pernyataan tidak pernah tidak berdampak dalam menilai faktor ekstenal yang mempengaruhi piutang tak tertagih.

Selanjutnya yaitu hasil survei dengan menggunakan kuesioner maka didapat jawaban untuk setiap pernyataan variabel piutang tak tertagih yaitu:

Tabel 3. Distribusi Frekuensi Piutang Tak Tertagih

\begin{tabular}{|c|c|c|c|c|c|c|c|c|c|c|}
\hline \multirow[t]{2}{*}{ Pernyataan } & \multicolumn{2}{|c|}{$\begin{array}{l}(1) \\
\text { Tidak } \\
\text { Pernah }\end{array}$} & \multicolumn{2}{|c|}{ (2) Jarang } & \multicolumn{2}{|c|}{$\begin{array}{l}\text { (3) Kadang - } \\
\text { kadang }\end{array}$} & \multicolumn{2}{|c|}{ (4) Sering } & \multicolumn{2}{|c|}{ (5) Selalu } \\
\hline & $\sum$ & $(\%)$ & $\sum$ & $(\%)$ & $\sum$ & $(\%)$ & $\sum$ & $(\%)$ & $\sum$ & $(\%)$ \\
\hline 1 & 0 & $0 \%$ & 2 & $6,1 \%$ & 21 & $63,7 \%$ & 6 & $18,1 \%$ & 4 & $12,1 \%$ \\
\hline 2 & 0 & $0 \%$ & 1 & $3 \%$ & 4 & $12,1 \%$ & 7 & $21,2 \%$ & 21 & $63,7 \%$ \\
\hline 3 & 0 & $0 \%$ & 2 & $6,1 \%$ & 10 & $30,3 \%$ & 6 & $18,1 \%$ & 15 & $45,4 \%$ \\
\hline 4 & 0 & $0 \%$ & 1 & $3 \%$ & 13 & $39,3 \%$ & 2 & $6,1 \%$ & 17 & $51,6 \%$ \\
\hline 5 & 0 & $0 \%$ & 9 & $27,3 \%$ & 18 & $54,6 \%$ & 5 & $15,1 \%$ & 1 & $3 \%$ \\
\hline 6 & 0 & $0 \%$ & 3 & $9,1 \%$ & 5 & $15,1 \%$ & 6 & $18,1 \%$ & 19 & $57,6 \%$ \\
\hline 7 & 0 & $0 \%$ & $\begin{array}{l}1 \\
3\end{array}$ & $39,3 \%$ & 18 & $54,5 \%$ & 2 & $6,1 \%$ & 0 & $0 \%$ \\
\hline 8 & 0 & $0 \%$ & $\begin{array}{l}1 \\
1\end{array}$ & $33,3 \%$ & 18 & $54,5 \%$ & 2 & $6,1 \%$ & 2 & $6,1 \%$ \\
\hline Total & 0 & & $\begin{array}{l}4 \\
2\end{array}$ & & 107 & & 36 & & 79 & \\
\hline
\end{tabular}

Dari pembahasan diatas dapat disimpulkan bahwa semua responden tidak ada yang memilih kategori pernyataan tidak pernah dalam menjawab pernyataan - pernyataan tentang piutang tak tertagih sehingga dapat dikatakan bahwa jawaban pernyataan tidak pernah tidak berdampak dalam menilai piutang tak tertagih dikoperasi.

\section{Pembahasan Hasil Penelitian}

\section{a. Hasil Uji Validitas}

Hasil uji validitas menggunakan bantuan program aplikasi SPSS Versi 20 dapat dilihat pada tabel berikut: 
Tabel 4. Hasil Uji Validitas Faktor Eksternal (X)

\begin{tabular}{|c|c|c|c|}
\hline No Item & Nilai Uji Validitas & Niai standar & Keterangan \\
\hline 1 & 0,491 & 0,3 & Valid \\
\hline 2 & 0,210 & 0,3 & Tidak Valid \\
\hline 3 & 0,619 & 0,3 & Valid \\
\hline 4 & 0,583 & 0,3 & Valid \\
\hline 5 & 0,586 & 0,3 & Valid \\
\hline 6 & 0,197 & 0,3 & Tidak Valid \\
\hline 7 & 0,255 & 0,3 & Tidak Valid \\
\hline 8 & 0,464 & 0,3 & Valid \\
\hline 9 & 0,467 & 0,3 & Valid \\
\hline 10 & 0,489 & 0,3 & Valid \\
\hline 11 & 0,557 & 0,3 & Valid \\
\hline 12 & 0,259 & 0,3 & Tidak Valid \\
\hline
\end{tabular}

Sumber : Output SPSS Versi 20

Berdasarkan hasil perhitungan uji validitas item pertanyaan dalam angket penelitian diperoleh item pertanyaan no 2, 6, 7 dan 12 tidak valid sehingga dikeluarkan dari angket penelitian, karena syarat minimum yang harus dipenuhi agar angket dikatakan valid adalah lebih besar dari 0,3 .

Tabel 5. Hasil Uji Validitas Piutang Tak Tertagih (Y)

\begin{tabular}{|c|c|c|c|}
\hline No Item & Nilai Uji Validitas & Nilai Standar & Keterangan \\
\hline 1 & 0,062 & 0,3 & Tidak Valid \\
\hline 2 & 0,692 & 0,3 & Valid \\
\hline 3 & 0,741 & 0,3 & Valid \\
\hline 4 & 0,587 & 0,3 & Valid \\
\hline 5 & 0,677 & 0,3 & Valid \\
\hline 6 & 0,839 & 0,3 & Valid \\
\hline 7 & 0,698 & 0,3 & Valid \\
\hline 8 & 0,716 & 0,3 & Valid \\
\hline
\end{tabular}

Sumber : Output SPSS Versi 20

Berdasarkan hasil uji validitas item pertanyaan dalam angket penelitian diperoleh item pertanyaan nomor 1 tidak valid sehingga dikeluarkan dari angket penelitian, karena syarat minimum yang harus dipenuhi agar angket dikatakan valid adalah lebih besar dari 0,3. Dengan demikian, maka proses selanjutnya adalah melakukan pengujian reliabilitas. 


\section{b. Uji Reliabilitas}

Berikut ini adalah tabel hasil uji reliabilitas:

Tabel 6. Hasil Uji Reliabilitas Faktor Eksternal (X)

\begin{tabular}{|r|r|}
\hline \multicolumn{2}{|c|}{ Reliability statistic } \\
\hline Croncbach's Alpha & N of Items \\
\hline, 754 & \\
\hline
\end{tabular}

Sumber : Output SPSS Versi 20

Dari tabel 6 diatas terlihat bahwa nilai reliabilitas variabel faktor eksternal yaitu 0,754> 0,60, sehingga hasil ini menunjukkan bahwa butir pertanyaan pada variabel faktor eksternal tersebut dapat dikatakan handal untuk mengukur variabelnya masing - masing. Hasil uji reliabilitas diperoleh variabel faktor eksternal reliabel sehingga dapat dilanjutkan ke uji regresi linear.

Tabel 7. Hasil Uji Reliabilitas Piutang Tak Tertagih (Y)

\begin{tabular}{|r|c|}
\hline \multicolumn{2}{|c|}{ Reliability statistic } \\
\hline Croncbach's Alpha & Nof Items \\
\hline, 805 & \\
\hline
\end{tabular}

Sumber : Output SPSS Versi 20

Dari tabel 7 diatas terlihat bahwa nilai reliabilitas variabel 0,805 $>0,60$, sehingga hasil ini menunjukkan bahwa butir pertanyaan pada variabel piutang tak tertagih tersebut dapat dikatakan handal untuk mengukur variabelnya masing - masing. Hasil uji reliabilitas diperoleh variabel piutang tak tertagih reliabel sehingga dapat dilanjutkan ke uji regresi linear.

\section{c. Analisis Regresi Linear Sederhana}

Tabel 8. Hasil Analisis Regresi Linear Sederhana Coefficients $^{\mathrm{a}}$

\begin{tabular}{|l|l|r|r|r|r|l|}
\hline \multirow{2}{*}{ Model } & \multicolumn{2}{|c|}{$\begin{array}{c}\text { Unstandardized } \\
\text { Coefficients }\end{array}$} & $\begin{array}{c}\text { Unstandardize } \\
\text { d Coefficients }\end{array}$ & $\mathrm{t}$ & \multirow{2}{*}{ Sig. } \\
\cline { 2 - 5 } & $\mathrm{B}$ & Std. Error & Beta & \\
\hline 1 & (Contans) & 15.125 & 2.715 & & 5.572 & .000 \\
\hline & $\begin{array}{l}\text { Piutang Tak } \\
\text { Tertagih }\end{array}$ & .559 & .106 & .688 & 5.275 & .000 \\
\hline
\end{tabular}

a. Dependent Variable: faktor eksternal

Sumber : Output SPSS Versi 20 
Dilihat dari hasil output tersebut, berdasarkan pengujian berdasar analisis regresi yang telah dilakukan maka didapatkan persamaan regresi seperti yang ditunjukkan pada model dibawah ini:

$$
\begin{aligned}
& Y=\alpha+\beta X+e \\
& Y=15,125+0,559 X+e
\end{aligned}
$$

Interpretasi hasil uji regresi sederhana dapat dilihat sebagai berikut:

- Nilai $\alpha$ atau konstanta sebesar 15,125 menunjukkan bahwa jika faktor eksternal nilainya sebesar 0 maka piutang tak tertagih di Koperasi Guru Rambate Rata (KGRR) Tinambung, Kabupaten Polewali mandar akan menjadi 15,125.

- Nilai koefisien regresi $\beta$ sebesar 0,559 menunjukkan bahwa jika faktor eksternal naik sebesar 1 satuan (kali) maka piutang tak tertagih di Koperasi Guru Rambate Rata (KGRR) Tinambung, Kabupaten Polewali Mandar akan naik sebesar 0,559, dan sebaliknya jika faktor eksternal turun sebesar 1 satuan (kali) maka piutang tak tertagih di Koperasi Guru Rambate Rata (KGRR) Tinambung, Kabupaten Polewali mandar akan turun sebesar 0,559

\section{d. Uji t Statistik}

Uji $\mathrm{t}$ digunakan untuk mengetahui pengaruh variabel independen dengan variabel dependen. Adapun kriteria uji t yaitu:

Jika t hitung faktor eksternal $\leq \mathrm{t}$ tabel maka $\mathrm{H} 0$ diterima

Jika $t$ hitung faktor eksternal $\geq \mathrm{t}$ tabel maka $\mathrm{H} 0$ ditolak

Adapun hasil Uji t statistik yaitu sebagai berikut:

\section{Faktor Eksternal (X)}

Karena $\mathrm{t}$ hitung 5,275 > t tabel 2,0349 maka H0 ditolak, yang artinya yaitu faktor eksternal berpengaruh positif dan signifikan terhadap piutang tak tertagih di Koperasi Guru Rambate Rata (KGRR) Tinambung, Kabupaten Polewali Mandar atau Karena sig 0,000<0,05 maka H0 ditolak, yang artinya yaitu faktor eksternal berpengaruh positif dan signifikan terhadap piutang tak tertagih di Koperasi Guru Rambate Rata (KGRR) Tinambung, Kabupaten Polewali mandar.

\section{e. Koefisien Determinasi}

Koefisien Determinasi digunakan untuk mengetahui hubungan antara satu variabel dengan variabel lain. Adapun hasil uji koefisien determinasi dapat dilihat pada tabel berikut: 
Tabel 9. Hasil Uji Koefisien Determinasi

\begin{tabular}{|l|l|l|l|l|}
\hline Model & $\mathrm{R}$ & R Square & $\begin{array}{l}\text { Adjusted R } \\
\text { square }\end{array}$ & $\begin{array}{l}\text { Std. Error of } \\
\text { the Estimate }\end{array}$ \\
\hline 1 & $.688^{\mathrm{a}}$ & .473 & .456 & 2.61435 \\
\hline
\end{tabular}

a. predictors: (Constant), piutang tak tertagih

Sumber : Output SPSS Versi 20

Berdasarkan tabel diatas dapat dilihat dari table adjusted $\mathrm{R}$ square yang menunjukkan angka sebesar 0,456 yang artinya sumbangan dari variabel faktor eksternal dan piutang tak tertagih terhadap variabel profitabilitas adalah sebesar $45,60 \%$ sedangkan sisanya sebesar $54,40 \%$ dipengaruhi oleh faktor lain yang tidak teliti. Nilai koefisien determinasi yang kecil menunjukkan bahwa kemampuan variabel faktor eksternal (independen) dalam menjelaskan variasi variabel piutang tak tertagih (dependen) terbatas.

Selain proses terjadinya piutang tak tertagih di Koperasi Guru Rambate Rata (KGRR) Tinambung Kabupaten Polewali Mandar dipengaruhi oleh faktor eksternal juga dipengaruhi oleh faktor lain yang tidak diteliti oleh peneliti, faktor lain tersebut yaitu faktor internal. Faktor internal merupakan faktor yang berasal dari dalam pihak koperasi. Faktor internal ini juga ikut berpengaruh terhadap proses terjadinya piutang tak tertagih di Koperasi Guru Rambate rata (KGRR) Tinambung. Faktor - faktor internal tersebut antara lain yaitu :

a. Lemahnya proses penagihan oleh pihak koperasi

b. Kurang tegasnya kebijakan atau syarat - syarat pemberian pinjaman yang diberikan oleh pihak koperasi.

c. Kurang terkontrolnya anggota oleh pihak koperasi sehingga ada sebagian kecil anggota koperasi mempunyai pinjaman ditempat lain selain di Koperasi seperti di bank.

\section{KESIMPULAN DAN SARAN}

Berdasarkan analisis data peneliti, diperoleh kesimpulan bahwa faktor eksternal berpengaruh positif terhadap piutang tak tertagih di Koperasi Guru Rambate Rata (KGRR) Tinambung, Kabupaten Polewali Mandar. Besarnya kontribusi yang diberikan adalah sebesar $45,60 \%$ sedangkan sisanya sebesar 54,40\% dipengaruhi oleh faktor lain yang tidak diteliti. Faktor lain yang dimaksud yaitu faktor Internal yang berasal dari dalam koperasi diantaranya yaitu: 
a. Lemahnya proses penagihan oleh pihak koperasi

b. Kurang tegasnya kebijakan atau syarat - syarat pemberian pinjaman yang diberikan oleh pihak koperasi.

c. Kurang terkontrolnya anggota oleh pihak koperasi sehingga ada sebagian kecil anggota koperasi mempunyai pinjaman ditempat lain selain di Koperasi seperti di bank.

Berdasarkan hasil penelitian, maka dapat diberikan saran - saran sebagai berikut:

a. Bagi pihak koperasi, dengan adanya penelitian ini diharapkan dalam menentukan kebijakan - kebijakan khususnya dalam masalah pemberian pinjaman kepada anggota koperasi diharapkan harus benar - benar melakukan pertimbangan - pertimbangan tertentu seperti menganalisa kondisi keuangan, karakter, dan latar belakang kehidupan anggota yang ingin diberikan pinjaman agar dapat mengantisipasi tidak terjadinya piutang tak tertagih dan juga diharapkan agar lebih tegas dalam menangani masalah anggota yang mempunyai piutang tak tertagih.

b. Bagi seluruh mahasiswa dan mahasiswi diharapkan penelitian ini dapat bermanfaat dan menambah wawasan mengenai faktor eksternal yang mempengaruhi piutang tak tertagih pada koperasi.

c. Bagi peneliti, diharapkan bagi penelitian selanjutnya yang berkaitan dengan piutang tak tertagih dapat lebih menyempurnakan dan mengkaji lebih lanjut faktor - faktor lain selain faktor eksternal yang mempengaruhi piutang tak tertagih. Contohnya faktor internal yang mempengaruhi piutang tak tertagih

\section{DAFTAR PUSTAKA}

Feryanto, Agung. 2010. Buku Panduan pendidik Ekonomi. Klaten: Intan Pariwara.

Ghozali, Imam. 2012. Aplikasi Analisis Multivariate dengan Program IMB SPSS 20. Semarang: Badan Penerbit - Universitas Diponegoro.

Hery. 2014. Akuntansi Aset, Liabilitas dan Ekuitas. Jakarta: PT GramediaWidiasarana Indonesia.

Kieso, dkk. 2009. Akuntansi Intermediate Jilid I. Jakarta: Salemba Empat. . 2013. Pengantar Akuntansi, Edisi 7. Jakarta: Salempa Empat

Martini, Dwi. 2012. Akuntansi Keuangan Menengah Berbasis PSAK Jilid I. Jakarta: Salemba Empat.

Mulya, Hadri. 2010. Memahami Akuntansi Dasar Edisi 2. Jakarta: Mitra Wacana Media.

Rivai dkk, Veithzal. 2013. Manajemen Perbankan dari Teori ke Praktik.Jakarta: Raja Grafindo Persada.

Sugiri, Slamet. 2009. Akuntansi Pengantar 2. Yogyakarta: UPPM STIM YKPN

Sugiyono. 2016. Metode Penelitian Kuantitati, Kualitatif dan R\&D. Bandung: Alfabeta.

Suyatno, Tomas dkk. 2007. Dasar - Dasar Perkreditan Edisi Empat. Jakarta: PT. Gramedia Pustaka Utara. 